\title{
Nutrient distribution among metabolic fractions in 2 Atriplex spp.
}

\author{
MUHAMMAD ISLAM AND MARK A. ADAMS
}

Authors are graduate student, Plant Sciences, Faculty of Agriculture, University of Western Australia, Nedlands, Western Australia 6907, Australia, and associate professor, Botany Department, University of Western Australia, Nedlands, Western Australia 6907, Australia.

\begin{abstract}
The seasonal variations in nitrogen and phosphorus fractions and cations in 2 species of Atriplex common to Western Australia (Atriplex amnicola P. G. Wilson and Atriplex nummularia Lindl.) were investigated. Both species contain high concentrations of nitrogen $(\mathrm{N})$ in winter as compared with summer when both species contain high concentrations of sodium. The sum of soluble protein-N, amino acid-N, nucleic acid-N and nitrate- $\mathrm{N}$ is about half of the total nitrogen. The remainder includes non-soluble protein- $\mathrm{N}$ and other $\mathrm{N}$ associated with cell membranes and walls. Phosphorus was more uniformly distributed among pools of inorganic-P, phytate-P, nucleic acid-P and other (residual) fractions. We suggest that interpretation of animal nutrition studies based on similar trichloroacetic acid (TCA) fractionations might be improved by independent estimation of soluble proteins. Fractionation using TCA provides valuable information about the subcellular distribution of both $\mathrm{N}$ and $\mathrm{P}$ in foliage tissues for studies of plant physiology and animal nutrition.

Concentrations of major nutrients in foliage of both species were significantly and negatively correlated with monthly maximum temperature and significantly and positively correlated with monthly rainfall. In summer and early autumn the apparent nutritive value of both species is well below the basic requirement of sheep or other grazing ruminants such as goats.
\end{abstract}

Key Words: Atriplex spp., saltbush, nitrogen, phosphorus, fractionation, animal nutrition, salinity

Salinity adversely affects the growth and metabolism of many plant species (Greenway and Munns 1980, Flowers et al. 1986, Munns 1993). In arid and semi-arid regions of the world, grasses, herbs and shrubs that can survive in saline soils have been the subject of considerable research. For example, halophytic shrubs have been evaluated as alternative sources of forage for livestock, and Atriplex spp. (saltbush) are strong candidates for cultivation in saline areas because of their salt tolerance and productivity (Kleinkopf et al. 1975, O'Leary et al. 1986, Malcolm 1994).

Physiological adaptations of Atriplex spp., including the accumulation of high concentrations of sodium and chloride within cell vacuoles and compatible organic solutes in cytoplasm (Cheeseman 1988, Adams et al. 1992), help offset the growthlimiting attributes of soil salinity. $\mathrm{Na} / / \mathrm{H}+$ exchangers or "antiporters" at the tonoplast that can increase $\mathrm{Na}+$ accumulation

Manuscript accepted 25 April 1999.
Resumen

Se investigo la variación estacional de las fracciones de nitrógeno, fósforo y cationes de dos especies de Atriplex comúnes del oeste de Australia (Atriplex amnicola P.G. Wilson y Atriplex nummularia Lindl.). En invierno, ambas especies contienen altas concentraciones de nitrógeno $(\mathrm{N})$, comparado con el contenido de verano cuando tienen altas concentraciones de sodio. La suma del $\mathrm{N}$-protéico soluble, $\mathrm{N}$-amino ácidos, $\mathrm{N}$ - nucleico y el $\mathrm{N}$ nitratos es aproximadamente la mitad del nitrógeno total. El nitrógeno restante incluye el $\mathrm{N}$-protéico no soluble y el $\mathrm{N}$ asociado con las membranas y paredes celulares. El fósforo (P) estuvo mas uniformemente distribuido entre las fracciones de $P$ inorgánico, P-ácido nucleico y otras fracciones (residuales). Sugerimos que la interpretación de los estudios de nutrición animal basados en el fraccionamiento de ácido tricloroacético similar (TCA), pudiera ser mejorada por la estimación independiente de las proteínas solubles. El fraccionamiento utilizando TCA provee valiosa información acerca de la distribución subcelular del $\mathbf{N}$ y $\mathbf{P}$ en los tejidos foliares,información util en los estudios de fisiología vegetal y nutrición animal.

Las concentraciones de los principales nutrientes en el follaje de ambas especies fueron significativamente y negativamente correlacionadas con la temperatura máxima mensual y significativamente y positivamente correlacionadas con la lluvia mensual. En verano e inicios de otoño el valor nutritivo aparente de ambas especies es menor que los requerimientos básicos de los ovinos y otras especies de rumiantes tales como los caprinos.

in the vacuole of halophytes, have been suggested as further adaptations to salinity (Staal et al. 1991, Barkala et al. 1995).

The nutritive value of Atriplex spp. and other native shrubs for grazing animals has been studied using a variety of techniques (Wilson 1977, Wilson and Graetz 1980, Warren and Casson 1991) which are often based on the work of Van Soest and colleagues (Crooker et al. 1978, Krishnamoorthy et al. 1982, Sniffen et al. 1992, Van Soest 1994). Laboratory procedures for determining nutritive value utilise a range of chemical extractions, especially tungstic and trichloroacetic (TCA) acid in combination with detergents, to fractionate the nitrogen and protein content of plant material into categories which differ in their digestibility (e.g. Licitra et al. 1996). These developments in methodology for studying animal nutrition parallel development of methods for studying plant physiology. For example, Kedrowski (1983) and Chapin and Kedrowski (1983) used a TCA-based fractionation to separate foliar $\mathrm{N}$ into classes that differed metabolically and as 
sinks for the storage and retranslocation of $\mathrm{N}$ both seasonally and with treatment. This method has since been applied to organic$\mathrm{N}$ in litter with similar results (Polglase et al.1992).

Despite methodological advances in both animal nutrition and plant physiology, there is not always an exact relationship between measured attributes of plants and their value to stock. A piece of longheld, and still conventional, wisdom is that protein concentrations are the major index of nutritive value and can be calculated from the concentration of total nitrogen using a 'conversion factor' (e.g. concentration of protein $=6.25 \mathrm{x}$ concentration of Kjeldahl N). On this basis, the National Academy of Science (1958) reported that the concentration of crude protein in Atriplex ranges from about $6 \%$ to $24 \%$ and others have argued similarly (Beadle et al.1957, Malcolm 1994). While the foliage of Atriplex spp. may contain high concentrations of $\mathrm{N}$, there are no definitive studies of the distribution of this nitrogen among classes now commonly accepted in studies of animal nutrition or plant physiology (as identified above). For example, as much as half of total $\mathrm{N}$ in Atriplex is non-protein nitrogen and of less certain value to grazing animals (Gihad and El Shear 1994).

Further examination of the accumulation of salts and nitrogen fractions in saltbush, and their relationship with soil salinity and climatic factors, are needed before we can accurately evaluate their role as animal fodder. The present study investigated: (a) the relationship between the nutritive value of foliage of 2 Atriplex spp. and environmental factors, such as rainfall and temperature; and, (b) the distribution of total nitrogen and phosphorus (elements that limit growth in Western Australian soils) among discrete 'fractions' in the foliage. We compared 2 perennial species, A. amnicola $\mathrm{P}$. G. Wilson (River saltbush) and A. nummularia Lindl.(Old man saltbush).

\section{Materials and Methods}

\section{Study sites}

Field work for this study was conducted between February 1995 and January 1996 at a 10 ha site close to Tammin ( $31^{\circ} 39^{\prime} \mathrm{S}$, $117^{\circ} 29^{\prime} \mathrm{E} ; 200 \mathrm{~km}$ east of Perth, Western Australia). The site has been previously described by Davidson et al. (1991). Briefly, the soil is saline (conductivity of $60-80 \mathrm{ds} / \mathrm{m}$ ) and has a high sodium absorption ratio (SAR) 80-100. The surface soil horizon lies above a dense clay B horizon and may become waterlogged after rain. The 2 species of saltbush have been grown side by side on the same site for more than 18 years. The species were planted in alternate rows on a $2.5 \times 2.5 \mathrm{~m}$ grid along a topographic gradient of soil salinity (from low to high salinity).

The climate of the study area is semiarid, with considerable seasonal and daily variations in temperature. Precipitation and temperature data were obtained from meteorological stations at Tammin and Cunderdin, less than $25 \mathrm{~km}$ away from the study site. Mean maximum temperature for the hottest month during the study (January) was $34^{\circ} \mathrm{C}$ and the mean minimum for the coldest month (July) was $7^{\circ} \mathrm{C}$ (Fig. 1a). Total precipitation during the study period was $437 \mathrm{~mm}$ and almost half of that fell between June and August (Fig. 1b). These values are all close to the long term means for Tammin, and evaporation exceeds precipitation for much of the year.

\section{Sampling}

Leaf samples were collected from 6 randomly selected plants of $A$. amnicola and A. nummularia at monthly intervals starting in February 1995 along the topographic salinity gradient. Leaf samples were immediately plunged into liquid $\mathrm{N}_{2}$ and freezedried on return to the laboratory. All analyses were conducted on freeze-dried tissues and were made in duplicate. Mean values were used for statistical analyses.

\section{Chemical analysis}

Total nitrogen and phosphorus concentrations were measured by digestion of dried and ground leaf samples in $\mathrm{H}_{2} \mathrm{SO}_{4} / \mathrm{H}_{2} \mathrm{O}_{2}$ at $320^{\circ} \mathrm{C}$ (Adams and Attiwill 1986) and subsequent colorimetric determination of $\mathrm{PO}_{4}^{3-}$ and $\mathrm{NH}_{4}{ }^{+}$. The method of Murphy and Riley (1962) was used to measure $\mathrm{PO}_{4}{ }^{3-}$ and the indophenol
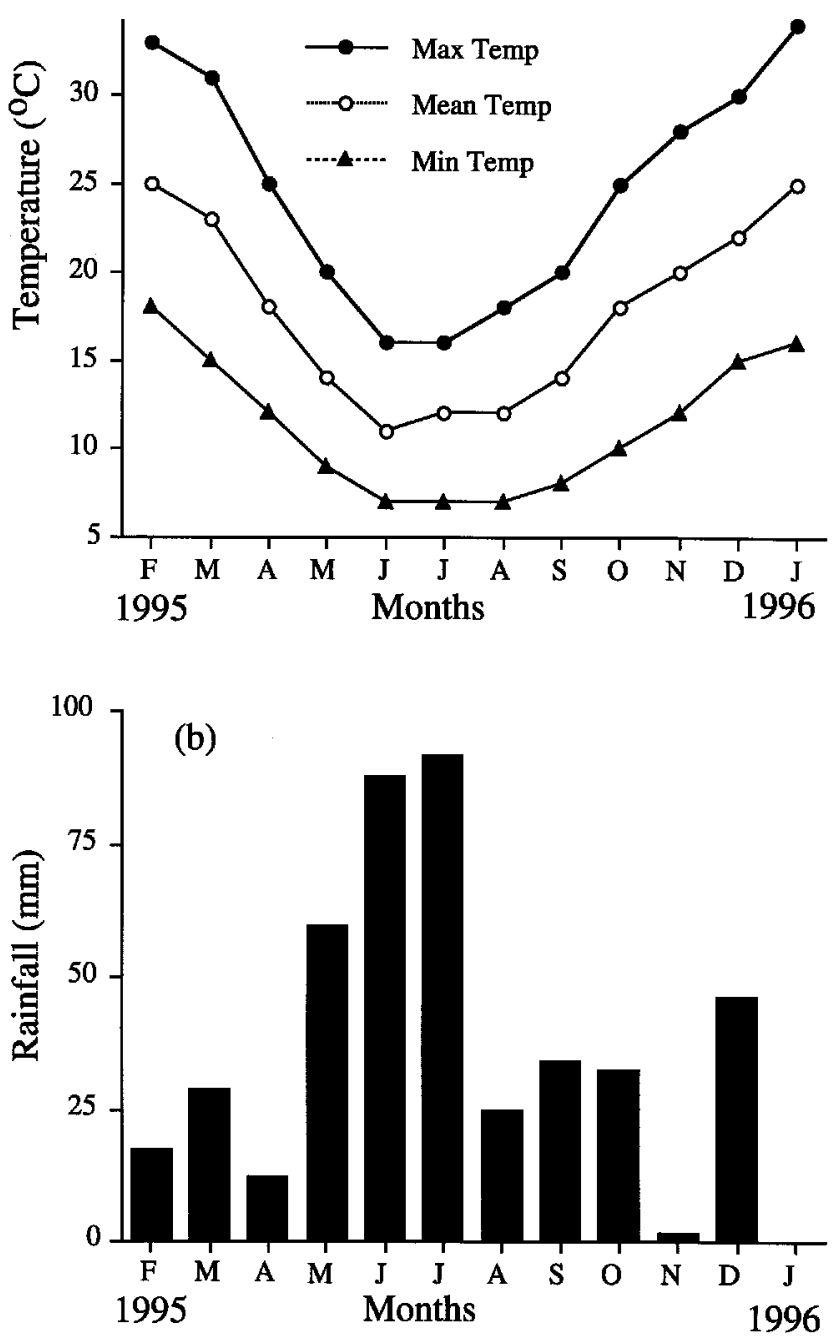

Fig. 1. Climatic conditions at Tammin, Western Australia, from February 1995 to January 1996. (a) Monthly maximum, minimum and mean ambient temperatures. (b) Monthly rainfall. 

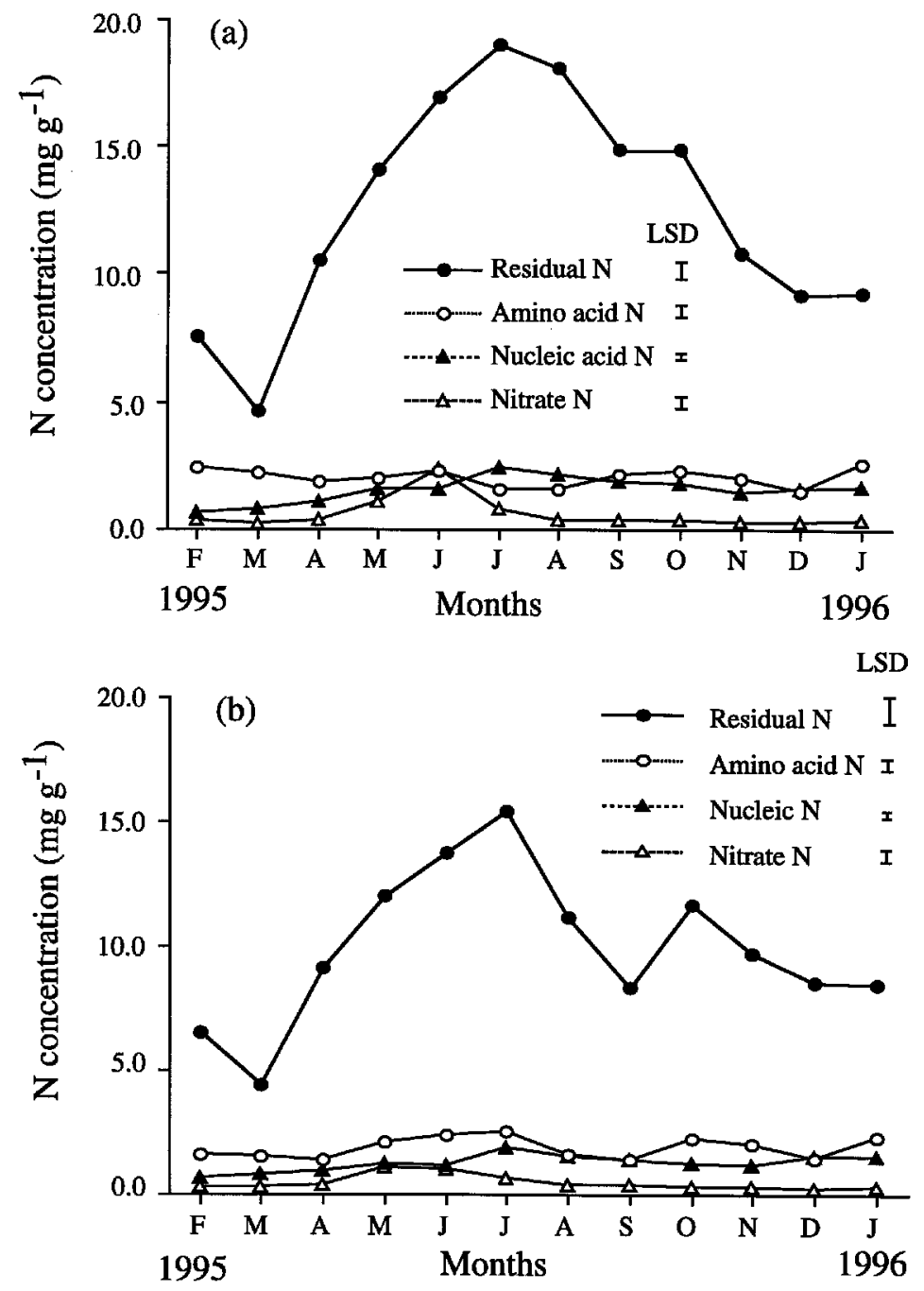

Fig. 2. Seasonal pattern of $\mathbf{N}$ fractions in (a) A. amnicola and (b) A. nummularia. Least significant differences for $p=0.05$ (LSD) between months for each fraction are shown.
$\left(\mathrm{P}_{\mathrm{o}}\right)$ soluble in cold TCA was assumed to be a combination of phytate $\mathrm{P}$ and other ester $\mathrm{P}$, and $\mathrm{P}_{\mathrm{O}}$ soluble in hot TCA to be a combination of phytate $\mathrm{P}$ and nucleic acid $\mathrm{P}$. The sum of $\mathrm{P}$ and $\mathrm{N}$ fractions in cold and hot TCA extracts we defined as labile $\mathrm{P}$ and labile N (Polglaze et al. 1992). Residual components were defined as those insoluble in TCA.

Nitrate $\left(\mathrm{NO}_{3}{ }^{-}\right)$concentrations in foliage were measured separately by the extraction and analysis procedures described by Cataldo et al. (1975). The total concentrations of $\mathrm{Na}^{+}, \mathrm{K}^{+}, \mathrm{Ca}^{2+}$ and $\mathrm{Mg}^{2+}$ were determined by digestion of leaf samples in acid (as described above for analysis of total $\mathrm{N}$ and $\mathrm{P}$ ) followed by atomic absorption spectroscopy (e.g. Adams and Attiwill 1986).

Soluble protein was determined by a modified procedure of Wilkins et al. (1994) with $50 \mathrm{mg}$ of leaf tissues homogenised with $1.2 \mathrm{ml}$ of $100 \mathrm{mM}$ Tris $/ \mathrm{HCl} \mathrm{pH} 7.6$, containing $1.5 \mathrm{mM}$ disodium ethylenediamine tetraacetic acid (EDTA), $1.5 \mathrm{mM}$ $\mathrm{MgCl}_{2}, 1.5 \mathrm{mM} \mathrm{KHCO}{ }_{3}, 2.5 \%$ (v/v) Tween 20, $10 \%(\mathrm{v} / \mathrm{v})$ glycerol, $100 \mathrm{mg}$ of sand and $10 \%(\mathrm{w} / \mathrm{v})$ insoluble polyclar AT. The crude extracts were centrifuged at $15,000 \mathrm{~g}$ for 5 minutes, decanted and the supernatant re-centrifuged for $2 \mathrm{~min}$ at $15,000 \mathrm{~g}$. The clear extract was analysed for protein using the method of Lowry et al. (1951) with a kit purchased from Bio-Rad.

Statistical analysis was performed using the General Analysis of Variance procedure available in the Genstat computer package. Species and season were considered the independent variables. Harvest dates were treated as repeated measures in time and analysed using a randomised complete block design. blue method of Keeney and Nelson (1982) was used to measure $\mathrm{NH}_{4}{ }^{+}$.

Leaf $\mathrm{N}$ and $\mathrm{P}$ were fractionated using sequential extraction with cold (room temperature, $0.3 \mathrm{M})$ and hot $\left(90^{\circ} \mathrm{C}, 0.15 \mathrm{M}\right)$ trichloroacetic acid (TCA) by the procedure of Polglase et al. (1992) modified from Chapin and Kedrowski (1983). Usually, extracts would be analysed for inorganic and total $\mathrm{N}$ and $\mathrm{P}$ and the concentration of organic $\mathrm{N}$ and $\mathrm{P}$ calculated as the difference. Concentrations of inorganic $\mathrm{N}$ in cold TCA extracts were negligible and we assumed that the total $\mathrm{N}$ was derived largely from amino acids (Chapin and Kedrowski 1983). Similarly, hot TCA extracted mainly organic $\mathrm{N}$ (assumed to be nucleic acids) and there was little inorganic $\mathrm{N}$ present.

Inorganic phosphorus was present only in cold TCA extracts. Organic phosphorus

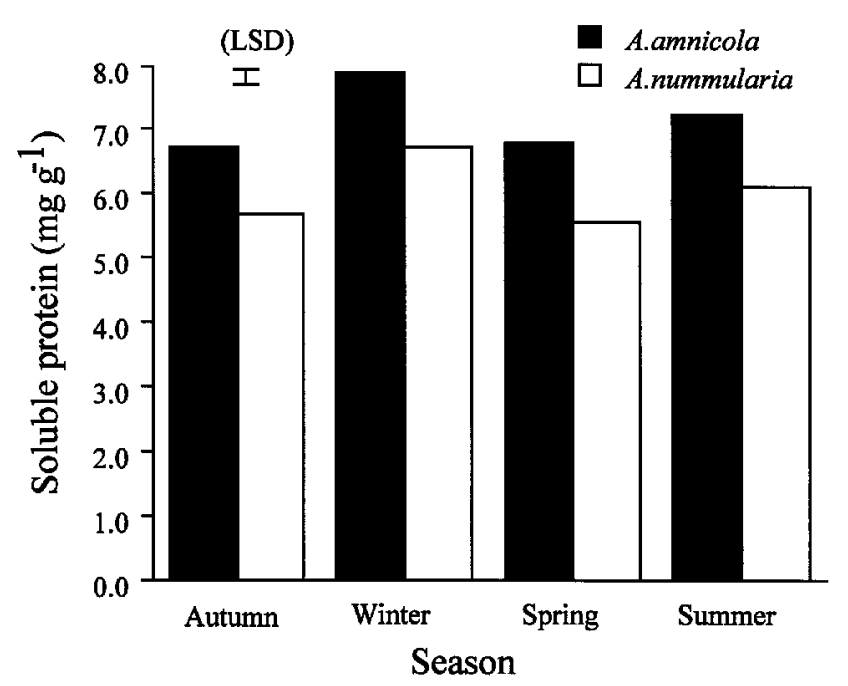

Fig. 3. Concentrations of soluble protein in foliage of $A$. amnicola and $A$. nummularia. The least significant difference for $p=0.05$ (LSD) between species for all seasons is shown. 


\section{Results}

\section{Nitrogen}

Concentrations of amino acid nitrogen (soluble in cold TCA) and nucleic acid nitrogen (soluble in hot TCA) for both species varied throughout the year (Figs $2 \mathrm{a}, 2 \mathrm{~b}$ ). In particular, concentrations of amino acid nitrogen were greatest in summer and early autumn (18-31\% of total nitrogen) and least in winter and spring (5-14\% of total nitrogen). Concentrations of nucleic acid nitrogen varied less (between 6 and 14\%) and little seasonal pattern was apparent. Separate analysis of nitrate concentrations in foliage of both species showed little seasonal trend but were greater during periods of rainfall (6$11 \%)$ than at other times $(2-4 \%)$. The concentrations of total nitrogen in leaves of both species were greatest in winter months and least in summer. The difference between total $\mathrm{N}$ and labile $\mathrm{N}$ (nucleic acid $\mathrm{N}+$ amino acid $\mathrm{N}+$ nitrate $\mathrm{N}$ ) we defined as residual $\mathrm{N}$ and comprised by far the largest $\mathrm{N}$ fraction throughout the year (Figs 3a, 3b).

Further estimates of the forms of $\mathrm{N}$ in foliage were obtained using a direct extraction technique for soluble protein. On a seasonal basis (Fig 3), concentrations of soluble protein were significantly greater in winter than in other seasons (on the basis of the ratio of protein: $\mathrm{N}$ of 6.25 , the approximate concentration of $\mathrm{N}$ in soluble protein varied between about 0.9 and $1.2 \mathrm{mg} \mathrm{N} \mathrm{g}^{-1}$ dry weight). Seasonal mean concentrations of total $\mathrm{N}$ and their distribution into residual and labile N (Fig 4) followed a similar pattern to those of soluble protein. The concentration of total $\mathrm{N}$ was significantly less in A. nummularia than in A. amnicola throughout the year $(\mathrm{p}<0.01)$.

\section{Phosphorus}

Phosphorus was more evenly distributed among fractions than was nitrogen (Figs 2a, 2b, 5a, 5b). Most fractions followed

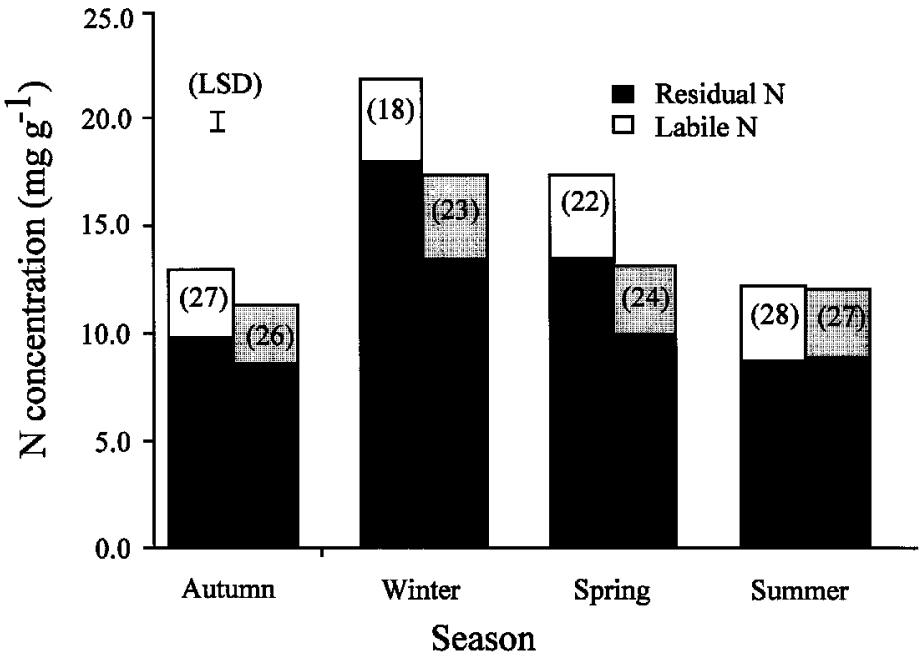

Fig. 4. Residual and labile $\mathrm{N}$ in $A$. amnicola (black and white) and $A$. nummularia (shaded). The least significant difference for $p=0.05$ (LSD) between species for total $\mathrm{N}$ for all seasons is shown. The proportion of labile-N as \% is given in brackets.

closely the pattern of rainfall (Fig 1b). Inorganic $\mathrm{P}$ comprised up to $60 \%$ of total leaf $\mathrm{P}$ in summer while phosphorus fractions soluble in hot TCA (phytate P plus nucleic acid P) increased to close to $40 \%$ of the total in winter. In contrast to nitrogen, residual phosphorus was the smallest fraction in both species throughout the year (Fig 6). Combination of monthly data into seasons shows clearly that total $\mathrm{P}$ concentrations were greatest in winter for both species and greater in A. amnicola than in A. nummularia ( $\mathrm{p}<0.01)$.

\section{Cations}

In $A$. amnicola and $A$. nummularia, the concentration of $\mathrm{Na}^{+}$was about $4.5 \%$ in mid-winter, and increased to maximum of $7-8 \%$ by mid-summer (Fig 7a, 7b). In both species the concentration of $\mathrm{K}^{+}$ increased in winter to $3 \%$ for A. amnicola and $3.6 \%$ for $A$. nummularia. The concentration of $\mathrm{K}^{+}$was significantly $(\mathrm{p}<0.01)$ greater in A. nummularia than A. amnicola during most of the year. In both species, the Na:K ratio in summer and autumn was greater than 3:1 compared with winter and spring when the ratio approached 1-1.5:1.

In A. amnicola, the concentration of $\mathrm{Mg}^{2+}$ in summer and autumn was $0.16 \%$, which increased to $0.21 \%$ in spring and winter. In A. nummularia, the concentration of $\mathrm{Mg}$ was about $0.10 \%$ in summer and autumn and $0.13 \%$ in winter and spring. In both species, the concentration of $\mathrm{Ca}^{2+}$ slightly increased in late autumn and winter $(0.99 \%)$, while remaining constant throughout the growing season.

\section{Correlation}

The concentrations of total nitrogen, nitrate, total phosphorus and potassium were significantly and negatively correlated with monthly mean maximum temperature $(p>0.05)$ and significantly and positively correlated with monthly rainfall $(\mathrm{p}<0.05)$. By contrast, sodium concentration was significantly and positively correlated with maximum mean monthly tem-

Table 1. Pearson correlation coefficients between environmental factors and concentrations of nutrients in Atriplex amnicola and Atriplex nummularia.

\begin{tabular}{|c|c|c|c|c|c|c|}
\hline & \multicolumn{3}{|c|}{ Atriplex amnicola } & \multicolumn{3}{|c|}{ Atriplex nummularia } \\
\hline & Max. Tem & Min Temp & Rainfall & Max. Temp & Min Temp & Rainfall \\
\hline Total Nitrogen & $-0.86^{* *}$ & $-0.87 * *$ & $0.59 *$ & $-0.73 * *$ & $-0.74 * *$ & $0.67 *$ \\
\hline Nitrate ( NO3) & $-0.60 *$ & $-0.58 *$ & $0.72 * *$ & $-0.69 *$ & $-0.66^{*}$ & $0.73 *$ \\
\hline Total Phosphorus & $-0.87 * *$ & $-0.86^{* *}$ & $0.77 * *$ & $-0.72 * *$ & $-0.73 * *$ & $0.67 * *$ \\
\hline Sodium & $0.94 * *$ & $0.90 * *$ & $-0.72 * *$ & $0.83^{* *}$ & $0.65^{*}$ & $-0.65 *$ \\
\hline Potassium & $-0.75 * *$ & $-0.66^{*}$ & $0.72 * *$ & $-0.84 * *$ & $-0.78 * *$ & $0.61 *$ \\
\hline Calcium & $-0.46 \mathrm{NS}$ & $-0.34 \mathrm{NS}$ & $0.41 \mathrm{NS}$ & $-0.71 * *$ & $-0.79 * *$ & $0.45 \mathrm{NS}$ \\
\hline Magnesium & $0.40 \mathrm{NS}$ & $-0.48 \mathrm{NS}$ & $0.16 \mathrm{NS}$ & $-0.63^{*}$ & $-0.64 *$ & $0.26 \mathrm{NS}$ \\
\hline
\end{tabular}

Significance $^{*} \mathrm{p}<0.05, * * \mathrm{p}<0.01, \mathrm{NS}=$ not-significant at $\mathrm{p} \leq 0.05$ 

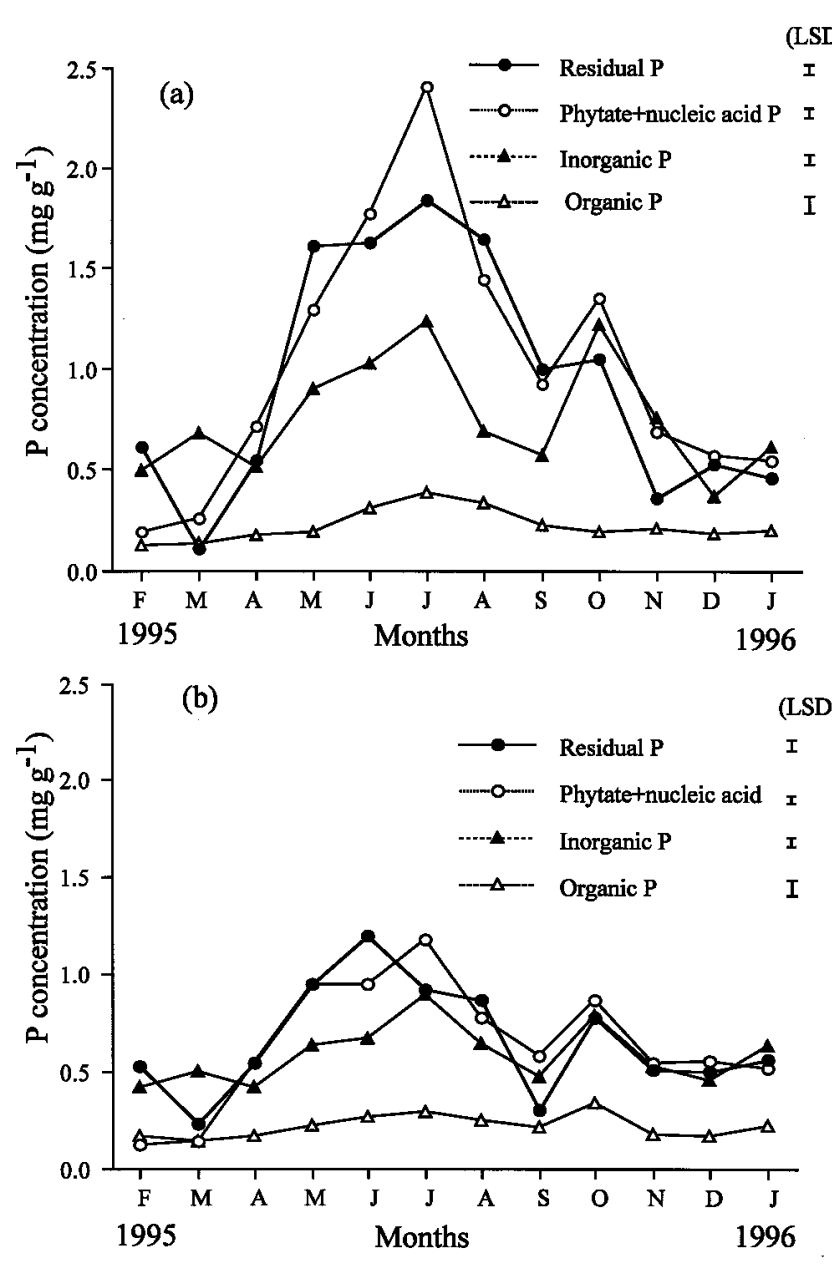

Fig. 5. Seasonal pattern of $P$ fractions in (a) A. amnicola and (b) $A$ nummularia. Least significant differences for $p=0.05$ (LSD) between months for each fraction are shown. nitrate- $\mathrm{N}$ were minor fractions showing little seasonal variation. Separate analysis suggested that the N-content of soluble protein was of the order of 1 $\mathrm{mg} \mathrm{g}^{-1}$ and hence the majority of the residual $-\mathrm{N}$ fraction of $10-18$ $\mathrm{mg} \mathrm{g}^{-1}$ is present as insoluble protein (probably associated with cell or organelle membranes) or cell wall components. The conflicting reports of digestibility and nutritive value for grazing animals of shrubs provide little by way of comparative data for the present study. Indeed, Le Houérou (1992) reported that the "feed value of Atriplex spp. has been questioned by a number of scientists and still is a controversial issue". Wilson (1977) assessed nitrogen fractions in a range of shrubs found in western New South Wales using methods based on acid and detergent fractionation. Wilson argued that the true digestibility (in sheep) of organic matter of 2 Atriplex species (including $A$. nummularia) was about $75 \%$, that of neutral-detergent fibre about $60 \%$, of acid-detergent fibre about $40 \%$ and of nitrogen about $95 \%$. In contrast, Le Houérou (1992) summarised a range of other studies in claiming a digestibility of nitrogen in Atriplex of only $65 \%$ and in addition pointed out that only about half of that was retained. The $\mathrm{N}$ not retained was largely glycinebetaine-a solute which accumulates during drought and especially salinity stress. In our study, glycinebetaine would have been included in the amino acid-N fraction which was always small and while glycinebetaines may reach micro-molar concentrations in salt-tolerant trees (Prat and Fathi-Ettai 1990) or shrubs under drought or saline conditions (Singh et al. 1973, Cyr et al. 1990, Storey et al. 1993, Kozlowski and Pallardy 1997) it is unlikely that this or other osmotically active nitrogenous solutes (e.g. proline) comprise a significant proportion of digestible- $\mathrm{N}$ in Atriplex. The increases in concentration of amino acid-N during summer were not reflected in total-N which declined possibly due to a) inhibition of nitrate reductase activity by water and salt stress (Hsiao 1973, Kleinkopf et al. 1975), b) $\mathrm{NH}_{4}{ }^{+} / \mathrm{Na}^{+}$competition (Naidoo 1987) or c) competition for sites of $\mathrm{NO}_{3}^{-}$uptake by $\mathrm{Cl}^{-}$on the basis that $\mathrm{Cl}^{-}$ is a major osmoticum in halophytes (Cram 1973).

Our finding that $\mathrm{N}$ in non-soluble protein or cell-walls is by far the largest pro- perature $(\mathrm{p}<0.01)$ and negatively with total monthly rainfall (Table 1). In both species, throughout the whole growing season, there were highly significant positive correlations between nitrogen and phosphorus concentration $(\mathrm{p}<0.01)$ and potassium concentration was negatively correlated $(p>0.01)$ with sodium concentration.

\section{Discussion}

Little, if any, attention has been given to the metabolic fractions of $\mathrm{N}$ and $\mathrm{P}$ in native Australian shrub species or indeed for many other, non-agricultural, trees and shrubs (Chapin and Kedrowski 1983). By far the greatest proportion of total $\mathrm{N}$ in Atriplex was present in the residual fraction that includes the soluble and non-soluble proteins and cell wall components and which varied considerably throughout the year. Amino acid-N, nucleic acid-N and

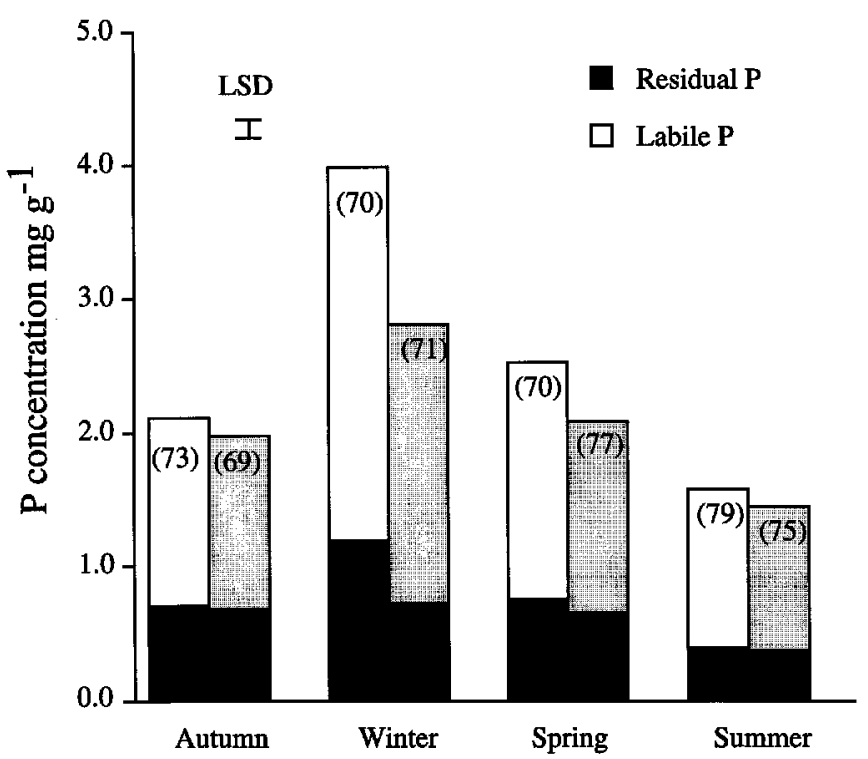

Fig. 6. Residual and labile $P$ in $A$.amnicola (black and white) and $A$. nummularia (shaded). The least significant difference for $p=0.05$ (LSD) between species for total $P$ for all seasons is shown. The proportion of labile-P is given in brackets. 


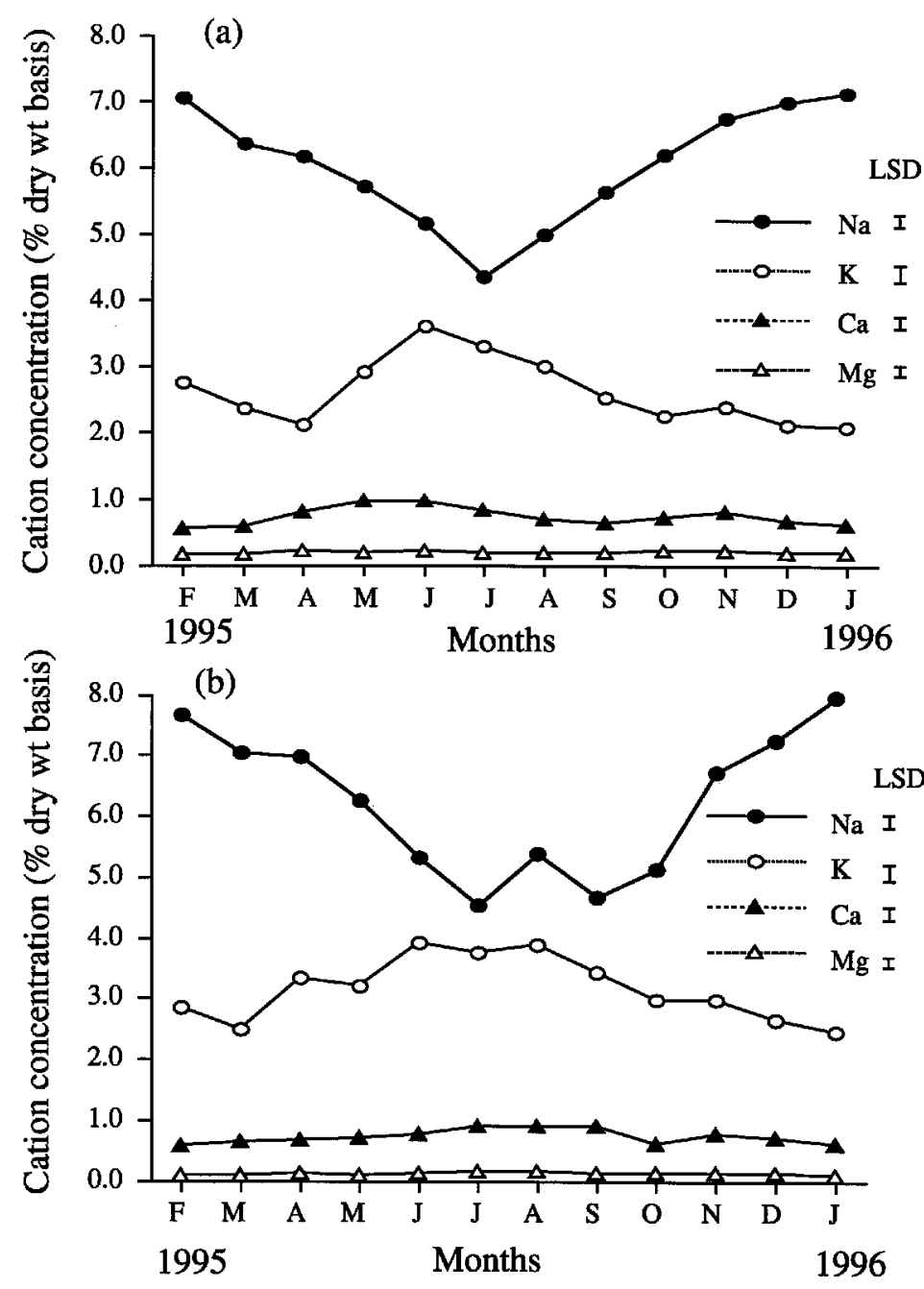

Fig. 7. Seasonal pattern of cation fractions in (a) A. amnicola and (b) A. nummularia. Least significant differences at $\mathbf{p}=\mathbf{0 . 0 5}$ (LSD) between months for each cation are shown.

portion of the largest $\mathrm{N}$-fraction (residual$\mathrm{N})$ which in turn strongly reflects seasonal fluctuations in growing conditions is consistent with other studies (Chatterton et al. 1971) and with the general physiological pattern that up to half of leaf $\mathrm{N}$ is associated with the membrane-associated enzymes of carbon fixation (e.g. RUBISCO, Field and Mooney 1986). It seems axiomatic that studies of plant $\mathrm{N}$ from the perspective of animal nutrition might benefit from a better understanding of the digestibility and retention of this $\mathrm{N}$ source.

Phosphorus, which has a central role in the energy metabolism of grazing animals as well as plants, was also lower in concentration in both species during summer and early autumn (Grice and Muir 1988) than recommended for grazing animals (0.16-0.37\%, National Research Council, 1975), but was adequate during the rest of the year. In summer, the concentration of inorganic phosphorus was greater than that of other P-fractions in both species. Inorganic-P acts as a P-storage pool in the vacuole and can be utilised during the summer period of intense growth (Marschner 1986). In winter, the increase in the phytate and nucleic acid P-fraction coincided with a comparable decline in inorganic phosphorus suggesting that $\mathrm{P}$ storage is a major process during the colder months.

Both Atriplex species contain considerably greater $\mathrm{Na}+$ concentrations than that recommended as being suitable for ruminants $(0.06 \%$ National Research Council 1981). In summer, both species contain more than $6 \%$ by weight of $\mathrm{Na}^{+}$. These high concentrations make Atriplex a poor quality forage and increase the demand of stock for good quality water (Grice and Muir 1988). Again, $\mathrm{K}^{+}$concentrations in both species were greater than those recommended by the National Research Council (1975, 1981 0.5-0.8\%). Low con- centrations of salts in foliage during winter may be a result of leaching from epidermal trichomes (salt bladders) which contain at least $50 \%$ of salt of the leaves (Pallaghy 1970).

In recent years, Atriplex spp. have increasingly been recognised as poor fodder for stock because of their high concentrations of salts and other metabolites, as found here, and due to the small proportion of total $\mathrm{N}$ present in readily digestible forms. In arid and semi-arid areas of developing countries, supplementary feeding will be necessary to overcome deficiencies in Atriplex as a stock feed (e.g. Le Houérou 1992). However, our results indicate that there is a substantial variation in the potential forage value throughout the growing season and this variation could be used to increase the value of saltbush for animals at specific times of the year. Clearly, any measure of "nutritional value" based on estimates of total $\mathrm{N}$ and thus "crude protein" are inaccurate. Notwithstanding, the fermentation and digestion capability of ruminant animals, alternative measures of the availability of $\mathrm{N}$ in foliage, may help in assessing the value of forage species in rangelands (and elsewhere).

\section{Literature Cited}

Adams, M.A. and P.M. Attiwill. 1986. Nutrient cycling and nitrogen mineralization in eucalypt forests of south-eastern Australia. 1 Nutrient cycling and nitrogen turnover. Plant and Soil 92:319-339.

Adams, P., J.C. Thomas, D.M. Vernon, H.J. Bohnert, and R.G. Jensen. 1992. Distinct cellular and organismic responses to salt stress. Plant Cell Phys. 33:1215-1223.

Beadle, N.C.W., R.D.B Whalley, and J.B.Gibson. 1957. Studies on halophytes II. Analytical data on the mineral constituents of three species of Atriplex and their accompanying soils in Australia. Ecol. 38:340-344.

Barkla, B.J., Z. Luisa, B. Eduardo, and J.AC. Smith. 1995. Tonoplast $\mathrm{Na}+\mathrm{H}+$ Antiport activity and its energization by the vacuolar $\mathrm{H}^{+}$-ATPase in the halophytic plant Mesembryanthemum crystallinum L. Plant Phys. 109:549-556.

Cataldo, D.A., M. Haroon, L.E. Schrader, and V.L. Youngs. 1975. Rapid colorometric determination of nitrate in plant tissue by nitration of salicylic acid. Communications in Soil Sci. and Plant Anal. 6:71-80.

Chapin, F. S III. and R. A. Kedrowski. 1983. Seasonal changes in nitrogen fraction and phosphorus fractions and autumn retranslocation in evergreen and deciduous taiga trees. Ecol. 64:376-391. 
Chatterton, N.J., J.R. Goodin, C.M. McKell, R.V. Parker, and J. M. Ribble. 1971. Monthly variation in the chemical composition of desert saltbush. J. Range Manage. 24:37-40.

Cheesman, J.M. 1988. Mechanisms of salinity tolerance in plants. Plant Phys. 87:547-550.

Cram, W.J. 1973. Internal factors regulating nitrate and chloride influx in plant cells. J. Exp. Botany. 24:328-341.

Crooker, B.A., C.J. Sniffen, W.H. Hoover, and L. L. Johnson. 1978. Solvents for soluble nitrogen measurements in feedstuffs. J. Dairy Sci. 61:437-447.

Cyr, D.R., G. Buxton, D.P. Webb, and E.B. Dumbroff. 1990. Accumulation of free amino acids in the shoot and roots of three northern conifers during drought. Tree Phys. 6:293-303.

Davidson, N.J., G. Galloway, and G. Lazersecu. 1991. Limits to the productivity of Atriplex in salt affected duplex soil. In: N. Davidson and R. Galloway (eds) Productive Use of Saline Land, Proceeding of a workshop held at Perth, Western Australia, 10-14 May 199. pp. 108-111. ACIAR Proceedings No. 42.

Field C. and H.A. Mooney 1986. The photosynthesis-nitrogen relationship in wild plants. In: T.J. Givinsh (ed) On the Economy of Plant Form and Function. pp. 25-55. Cambridge Univ. Press, Cambridge.

Flowers, T.J., M.A. Hajibagheri, and N.J.W. Clipson. 1986. Halophytes. Quarterly Review of Biology. 61:313-337.

Gihad, E.A. and H.M. El Shear. 1994. Utilization of halophytes by livestock on rangelands-Problems and prospects $I n$ : Victor R. Squires and Ali T.Ayoub (eds.). Halophytes as a Resource for Livestock and for Rehabilitation of Degraded Lands. pp 77-96. Kluwer Academic Publishers, London.

Greenway, H. and R. Munns. 1980. Mechanisms of salt tolerance in non-halophytes. Ann. Rev. Plant Phys. 31:149-190.

Grice, A. C. and S. J. Muir. 1988. Biology and management of saltbush and other chenopods. A review of current Australian literature on chenopods with emphasis on features of agriculture significance. E.Roberts (ed.), Div. of Agr.Serv., NSW.

Hsiao, T.C. 1973. Plant response to water stress. Ann. Rev. Plant Phys. 24:519-570.

Kedrowski, R.A. 1983. Extraction and analysis of nitrogen, phosphorus and carbon fractions in plant material. J. Plant Nutr. 6:989-1011.

Krishnamoorthy, U., T.V. Muscato, C.J. Sniffen and P.J. Van Soest. 1982. Nitrogen fractions in selected feedstuffs. J. Dairy Sci. 65:217-255.

Keeney, D.R. and W.D. Nelson.1982. Nitrogen-Inorganic forms. In: Methods of Soil Analysis Part 2 Chemical and Microbiological Properties 2nd (ed.) pp. 643-698. Amer. Soc. of Agron., Inc. Madison, Wisc. USA.

Kleinkopf, G.E., A. Wallace, and J.W. Cha. 1975. Sodium relations in desert plants: Some physiological responses of Atriplex confertifolia to different levels of sodium chloride. Soil Sci. 120(1):45-48.
Kozlowski, T.T. and S. G. Pallardy. 1997. Physiology of Woody Plants. Academic Press, USA.

Le Houérou, H.N. 1992. The role of saltbushes (Atriplex spp.) in arid land rehabilitation in the Mediterranean Basin: a review. Agroforest. Syst. 18:107-148.

Licitra, G., T.M. Hernandez, and P.J. Van Soest. 1996. Standardization of procedures for nitrogen fraction of ruminant feeds. Animal Feed Sci. Tech. 57:347-358.

Lowry, O.H., N.J. Rosebrough, A.L. Farr, and R.J. Randall. 1951. Protein Measurements with the Folin Phenol Reagent. J. Biol. Chem. 193:265-275

Malcolm, C.V. 1994. Use of halophyte forages for rehabilitation of degraded lands. In: Victor R.Squires and Ali T. Ayoub (eds.) Halophytes as a Resource for Livestock and for Rehabilitation of Degraded Lands. Kluwer Academic Publishers, London.

Marschner, H. 1986. Mineral Nutrition of Higher Plants, Academic Press, London

Munns, R. 1993. Physiological processes limiting plant growth in saline soils: some dogmas and hypotheses. Plant, Cell Environ. 16:15-24.

Murphy. J. and P.J Riley. 1962. A modified single solution method for determination of phosphate in natural water. Anal. Chimica Acta. 27:31-36.

Naidoo, G. 1987. Effects of salinity and nitrogen on growth and water relations in the mangrove, Avicennia Marina (Forsk) Vierh. New Phytol. 107:317-325

National Academy of Sciences-National Research Council. 1958. Composition of Cereal Grains and Forages. Publ. 585. Nat. Acad. of Sci.. Washington. D.C.

National Research Council. 1975. Nutrient requirements of domestic animals. Publication 5 Nutrient Requirements of Sheep. 5th revised ed Nat. Acad. of Sci. Washington, D.C

National Research Council. 1981.. Nutrient requirements of domestic animals. Publication 15 Nutrient Requirement of Goats. Nat. Acad. of Sci.Washington, D.C

O'Leary, J.W., E. P. Glenn, and M.C. Watson. 1986. Agricultural production of halophytes irrigated with sea water. Plant and Soil. 89: 311-321.

Pallaghy, C.K. 1970. Salt relations of Atriplex leaves. In: R.Jones. (ed) Biology of Atriplex. CSIRO Division of Plant Industry, Canberra.

Polglase, P.J., E.J. Jokela, and N.B. Comerford. 1992. Phosphorus, nitrogen and carbon fractions in litter and soil of Southern Pine plantations. Soil Sci. Soc. Amer. J. 56: 566-572.

Prat, D. and R.A. Fathi-Ettai. 1990. Variation in organic and mineral components in young Eucalyptus seedlings under saline stress. Physiol. Plant. 79:479-486.

Sniffen, C.J., J.D. O'Connor, P.J. Van Soest, D.G. Fox, and J.B. Russell. 1992. A net carbohydrate and protein system of evaluating cattle diets: Carbohydrate and protein availability. J. Anim. Sci. 70:3562-3577.

Staal, M., F.J.M. Maathuis, J.T.M. Elzenga,
J.H.M. Overbeek, and H.B.A. Prins.1991. $\mathrm{Na}^{+} / \mathrm{H}^{+}$antiport activity in tonoplast vesicles from roots of the salt tolerant Plantago mar itima and salt- sensitive Plantago media. Physiol. Plant. 82:179-184.

Singh, T.N., L.G. Paleg, and D. Aspinall. 1973. Nitrogen metabolism and growth in the barley plant during water stress. Aust. J. Biol. Sci. 26:45-56.

Storey, R.J. Gorham, M.G. Pitman, A.D. Hanson, and D. Gage. 1993. Response of Melanthera biflora to salinty and water stress. J. Exp. Bot. 44:1551-1560.

Van Soest, P.J. 1994. Nutritional Ecology of the Ruminant. 2nd (ed.) Cornell University Press. Ithaca, N.Y.

Warren, B.E. and T. Casson. 1991. Saltbush quality and sheep performance. In: N. Davidson and R. Galloway (eds) Productive Use of Saline Land, Proceedings of a workshop held at Perth, Western Australia, 10-14 May 199. pp. 71-74. ACIAR Proceedings No. 42.

Wilkins, D., J.J.VanOosten, and R.T. Besford. 1994. Effects of elevated $\mathrm{CO}_{2}$ on growth and chloroplast proteins in Prunus avium. Tree Physiol. 14:769-779.

Wilson, A.D. 1977. The digestibility and Voluntary Intake of the Leaves of Tress and Shrubs by Sheep and Goats. Aust. J. Agr. Res. 28:501-8.

Wilson, A.D. and R.D. Graetz. 1980. Cattle and sheep production on an Atriplex vesi caria (saltbush) community. Aust J. Agr.. Res. 31:369-78. 